\title{
Diagenetic Mg-calcite overgrowths on foraminiferal tests in the vicinity of methane seeps
}

Giuliana Panieri $^{1^{*}}$, Aivo Lepland ${ }^{1,2,3,4}$, Martin J. Whitehouse ${ }^{5}$, Richard Wirth ${ }^{6}$, Morten P. Raanes $^{7}$, Rachael H. James ${ }^{8}$, Carolyn A. Graves ${ }^{9}$, Antoine Crémière ${ }^{1,2}$, Andrea Schneider ${ }^{1}$

\begin{abstract}
Methane is a potent greenhouse gas and some episodes of past global warming appear to coincide with its massive release from seafloor sediments as suggested by carbon isotope records of
\end{abstract}


25 foraminifera. Here, we present structural, geochemical, and stable carbon isotope data from single

26 foraminiferal calcite tests and authigenic $\mathrm{Mg}$-calcite overgrowths in a sediment core recovered from

27 an area of active methane seepage in western Svalbard at ca. $340 \mathrm{~m}$ water depth. The foraminifera are

28 from intervals in the core where conventional bulk foraminiferal $\delta^{13} \mathrm{C}$ values are as low as $-11.3 \%$.

$29 \mathrm{Mg} / \mathrm{Ca}$ analyses of the foraminiferal tests reveal that even tests for which there is no morphological

30 evidence for secondary authigenic carbonate can contain $\mathrm{Mg}$-rich interlayers with $\mathrm{Mg} / \mathrm{Ca}$ up to 220

$31 \mathrm{mmol} / \mathrm{mol}$. Transmission electron microscopy (TEM) of the contact point between the biogenic

32 calcite and authigenic Mg-calcite layers shows that the two phases are structurally indistinguishable

33 and they have the same crystallographic orientation. Secondary ion mass spectrometry (SIMS)

analyses reveal that the Mg-rich layers are strongly depleted in ${ }^{13} \mathrm{C}\left(\delta^{13} \mathrm{C}\right.$ as low as $\left.-34.1 \%\right)$. These

very low $\delta^{13} \mathrm{C}$ values indicate that the authigenic $\mathrm{Mg}$-calcite precipitated from pore waters containing

methane-derived dissolved inorganic carbon at the depth of the sulfate-methane transition zone of methane seepage at the seafloor must be undertaken with care.

\section{Introduction}

42 Since the discovery of methane emissions at the seabed, investigators have explored the potential of using tests of modern and fossil calcitic foraminifera as archives of seepage history. Remarkable carbon isotope excursions (CIE), characterized by very low $\delta^{13} \mathrm{C}$ values in both benthic and planktonic foraminiferal calcite, have been interpreted to reflect widespread release of isotopicallylight carbon from dissociating marine methane hydrates during the Paleocene-Eocene Thermal Maximum (PETM) at 54.95 Ma (e.g., Dickens et al. 1995, Zachos et al. 2005). Massive methane releases have been also used to explain CIEs at other time intervals related to abrupt global warming

49 (Hesselbo et al., 2000, Jiang et al. 2003). However, it remains unclear if the very low $\delta^{13} \mathrm{C}$ values of 
50 foraminifera reflect $\delta^{13} \mathrm{C}$ values of dissolved inorganic carbon (DIC) in the primary biomineralization

51 environment or whether they are associated with secondary overgrowths of authigenic carbonate.

52 Very low $\delta^{13} \mathrm{C}$ values in foraminiferal calcite are widely considered to reflect seepage and

53 incorporation of methane-derived, ${ }^{13} \mathrm{C}$-depleted DIC at the time when foraminifera calcify their tests

54 (Wefer et al., 1994; Dickens et al., 1995; Kennett et al., 2000; Hill et al., 2004). Alternatively, low

55 foraminiferal $\delta^{13} \mathrm{C}$ values may reflect precipitation of secondary overgrowths of methane-derived

56 authigenic carbonates forming at the sulfate-methane transition zone (SMTZ) within subsurface

57 sediments (Torres et al., 2010; Millo et al., 2005; Martin et al., 2010; Panieri et al. 2014, 2015;

58 Consolaro et al., 2014). In this scenario, the original test surface merely acts as a template for

59 authigenic carbonate precipitation. At the depth of the SMTZ, upward migrating methane and

60 downward diffusing sulfate are consumed, by anaerobic oxidation of methane (AOM), according to

61 the reaction (Boetius, 2000):

$$
\mathrm{CH}_{4}+\mathrm{SO}_{4}^{2-} \rightarrow \mathrm{HCO}_{3}^{-}+\mathrm{HS}^{-}+\mathrm{H}_{2} \mathrm{O}
$$

63 The bicarbonate $\left(\mathrm{HCO}_{3}{ }^{-}\right)$ions produced by $\mathrm{AOM}$ react with calcium and magnesium ions present in

64 sediment pore waters to form Ca-Mg carbonates (Berner, 1970; Jørgensen et al., 2004; Ussler III and 65 Paull, 2008) which are typically strongly ${ }^{13} \mathrm{C}$ depleted.

66 Methane-derived authigenic calcite occurring as sediment cements or as overgrowths on foraminifera 67 tests are commonly rich in $\mathrm{Mg}$ with $\mathrm{Mg} / \mathrm{Ca}$ often $>20 \mathrm{mmol} / \mathrm{mol}$. $\mathrm{Mg}$ is effectively complexed by 68 sulfate in normal seawater which inhibits $\mathrm{Mg}$ incorporation into calcite, but if sulfate concentrations 69 are very low, e.g. in pore waters affected by AOM, Mg is not complexed and can be more readily 70 incorporated in calcite (Walter, 1986; Wright and Wacey, 2004). Hence Mg enrichment observed in 71 foraminiferal tests can be indicative of the presence of diagenetic phases.

72 Here we present the results of analyses of individual foraminifera tests in a sediment core from an 73 area of methane seepage west of Prins Karls Forland (ca. 340 m water depth), offshore western 
74 Svalbard (Fig. 1). Scanning Electron Microscope Energy Dispersive X-ray Spectroscopy (SEM-EDS),

75 Electron Probe Micro Analysis (EPMA), Transmission Electron Microscopy (TEM), and Secondary

76 Ion Mass Spectrometry (SIMS) studies reveal that there is significant variation in the geochemical

77 and carbon isotope compositions within individual tests, and highlight the complexity of

78 distinguishing primary vs. secondary signals. We demonstrate that diagenetic overprints on

79 foraminifera can be very extensive, but not always evident using traditional methods such as optical

80 microscopy and SEM.

81

82

\section{Material selection}

83 Foraminiferal tests were picked from three intervals (core depths 102, 132 and $210 \mathrm{~cm}$ below

84 seafloor (bsf); Table 1) within a $224 \mathrm{~cm}$ long sediment core PC06 (78:36.66 N; 9:25.53E; $374 \mathrm{~m}$

85 water depth) collected during RRS James Clark Ross cruise 253 in August 2011 (Fig. 1). The

86 present-day depth of the SMTZ in this core is $184 \mathrm{~cm}$ bsf, and all sediments from between 100 and

$87220 \mathrm{~cm}$ bsf contain foraminifera with distinctly negative bulk $\delta^{13} \mathrm{C}$ values (Panieri et al., 2016),

88 outside of the range of normal marine values (ca. -1 to $1 \%$ ). From each of the three selected

89 intervals calcitic tests of two benthic species, Nonionella labradorica (Dawson, 1860) and Melonis

90 barleeanus (Williamson, 1858), were chosen for detailed study to assess whether the low $\delta^{13} \mathrm{C}$ values

91 (Table 1) are associated with primary biogenic calcite, or secondary overgrowths.

\section{3. Strategy}

94 Sediment samples were washed through a $63 \mu \mathrm{m}$ sieve, and oven dried at $40{ }^{\circ} \mathrm{C}$. Tests of calcitic

95 benthic foraminifera, including both well preserved and altered (with obvious dissolution features

96 and overgrowths) specimens, were picked from the larger size fraction, $>100 \mu \mathrm{m}$, under a light

97 microscope. The selected specimens (F1-F5) are listed in Table 2, together with results of analysis of

98 the carbon isotope composition of bulk foraminifera (Panieri et al., 2016). 
3.1 Scanning Electron Microscope equipped with Energy Dispersive X-ray Spectroscopy (SEM101 EDS)

102 Polished cross-sections of a selection of tests were made by (i) placing the hand-picked tests on 103 adhesive tape in a circular $25 \mathrm{~mm}$ diameter mold, (ii) mounting using Struers Epofix, and (iii) 104 polishing to expose a cross-section through the interior of the tests. SEM-EDS examination of these 105 polished sections was carried out at The Arctic University of Norway using a SEM Hitachi Tabletop 106 Microscope TM-3000 equipped with Bruker Quantax 70 EDS Detector, and on a Zeiss Merlin 107 Compact VP with the GEMINI I electron column, and a Zeiss Sigma.

$109 \quad 3.2$ Electron Probe Micro Analysis (EPMA)

110 Quantitative Mg and Ca spot analyses and semi-quantitative elemental mapping were carried out 111 using a JEOL JXA-8500F electron microprobe (field-emission electron gun) equipped with a high 112 resolution wavelength X-ray dispersive spectrometer (WDS) at the Department of Materials Science 113 and Engineering in Trondheim. Diopside $\mathrm{MgCaSi}_{2} \mathrm{O}_{6}(\mathrm{Mg}=11.23 \mathrm{wt} \%)$ and $\mathrm{Calcite} \mathrm{CaCO}_{3}(\mathrm{Ca}=$ $11439.98 \mathrm{wt} \%$ ) were used as standards. The mapping was performed using a $0.1 \mu \mathrm{m}$ step size and beam 115 scan with an image resolution of 512 x 512 pixels, $10 \mathrm{kV}$ accelerating voltage and an electron beam 116 current of 20nA with a minimum probe size of 50nm. Under such microprobe conditions the electron 117 diffusion region of X-ray generation is in the range of $1 \mu \mathrm{m}$ (X-ray spatial resolution during mapping). 118 Optimum quantitative counting strategies from $\mathrm{Mg}$ and $\mathrm{Ca}$ were obtained with a total counting time 119 of 60 seconds in both peak and background position, from an excitation cross-section of approx. $2 \mu \mathrm{m}$. 120 The reproducibility of $\mathrm{Mg}$ and $\mathrm{Ca}$ determined from repeated analysis of standards was $<1.5 \%$, and 121 the detection limit was $\sim 100 \mathrm{ppm}$. Raw data were reduced to weight percentages using the ZAF 122 algorithm. Performing WDS on carbonate material can result in beam damage to the specimen and 123 lower counts compared to materials such as silicates. However, the ratio of $\mathrm{Mg}$ to $\mathrm{Ca}$ is not severely 
124 affected by these effects. Topographic variations and impurities within the foraminifera tests such as

125 clay particles and organic matter can influence the quantification of $\mathrm{Mg}$ and $\mathrm{Ca}$ in carbonate by

126 EPMA. To minimize these effects, the specimens were carefully examined by SEM- BSD/EDS, and

127 areas that appeared to be impurity-free were selected for EPMA.

$129 \quad 3.3$ Transmission Electron Microscopy (TEM)

130 Focused ion beam (FIB) milling was used as a sample preparation method for measurements

131 by transmission electron microscopy (TEM). FIB was conducted on a C-coated polished mount

132 to extract two foils from a single foraminifera test using a FEI FIB2000-TEM equipped with a

133 Ga-ion source at GeoForschungsZentrum Potsdam (GFZ; Germany). FIB milling occurred at 30

$134 \mathrm{keV}$. Final polishing of the surface with the ion beam almost parallel the surface occurred at a

135 beam current $11 \mathrm{pA}$. This leads to minimal damage to the outer layer (10 - $15 \mathrm{~nm})$ and, as the

136 thickness of the foil is $\sim 150 \mathrm{~nm}$, the crystalline state of the carbonate that is documented in

137 electron diffraction and lattice fringes, is unaffected. The experience of having cut more than

1385000 foils from different materials including many carbonates guarantees that a complete

139 amorphisation of the carbonates by Ga ion sputtering is excluded. The FIB-foil dimension was

$14015 \times 10 \times 0.15 \mu \mathrm{m}$ on average. Milled FIB foils were lifted out of the FIB sputtering site and

141 subsequently placed on standard Cu TEM grids covered with perforated amorphous carbon

142 film (Wirth, 2009). The TEM at GFZ used for this study was a FEI TecnaiG2 F20 X-TWIN

143 equipped with a Gatan Imaging Filter GIF (Gatan Tridiem, Gatan, CA, USA) EDAX X-ray analyzer

144 and a Fishione high-angle annular dark-field detector (HAADF). The electron source of the TEM

145 was a field emission gun emitter, operated at an acceleration voltage of $200 \mathrm{kV}$. EDX analyses

146 were performed in scanning transmission mode (STEM) by scanning the electron beam within

147 a preselected area. This technique minimizes mass-loss caused by electron sputtering. 
150 High spatial resolution carbon isotope analyses (c. $15 \mu \mathrm{m}$ analytical spots) were performed on two 151 mounted foraminifera tests using a CAMECA IMS 1280 large geometry Secondary Ion Mass 152 Spectrometry (SIMS) at the NordSIM facility in Stockholm, Sweden. A critically focused Cs 153 primary beam with $20 \mathrm{keV}$ impact was used to sputter the sample, and a low-energy electron154 flooding gun was used for charge compensation. The primary beam current was ca. $3 \mathrm{nA}$. Each 155 analysis consisted of an initial pre-sputter over a rastered $20 \mu \mathrm{m}$ area to remove the gold coating, 156 followed by centering of the secondary beam in the field aperture (field of view on the sample of 30 $157 \mu \mathrm{m}$ with 90x magnification transmission ion optics). Secondary ion signals were measured in 158 multicollector mode using a Faraday detector for ${ }^{12} \mathrm{C}^{-}\left(\mathrm{ca} .2 \times 10^{7} \mathrm{cps}\right.$ ), and an ion counting electron 159 multiplier for ${ }^{13} \mathrm{C}^{-}$at a mass resolution of ca. 4000, sufficient to resolve ${ }^{13} \mathrm{C}$ from ${ }^{12} \mathrm{C}^{1} \mathrm{H}$. A within run 160 correction was made for electron multiplier gain drift using the pulse height analysis curve. The 161 secondary magnet field was locked at high stability using a nuclear magnetic resonance field sensor 162 operating in regulation mode. All pre-sputter, beam centering and data acquisition steps were 163 automated in the run definition. Typical internal precision obtained for individual run ${ }^{13} \mathrm{C} /{ }^{12} \mathrm{C}$ ratios 164 from twenty-four cycles of 4-second integrations was ca. $0.2 \%$ (SE). Sample chamber vacuum was 165 maintained at $<2 \times 10^{-8}$ mbar.

166 Fully automated sequences comprised two measurements of the reference carbonate, Brown Yule 167 Marble calcite $\left(\mathrm{BYM}, \delta^{13} \mathrm{C}\right.$ VPDB $=-2.28 \%$, kindly provided by J. Craven, University of 168 Edinburgh), bracketing six measurements of unknown targets of the foraminiferal calcite and 169 authigenic $\mathrm{Mg}$-calcite. Calcite and $\mathrm{Mg}$-calcite can be expected to display different instrumental mass 170 fractionation (IMF) during SIMS analysis, hence using the same calcite reference material for 171 foraminiferal calcite and authigenic Mg-calcite may not be fully appropriate. An IMF bias between 172 calcite and various Mg-containing carbonates has been demonstrated for oxygen isotopes (Rollion173 Bard \& Marin-Carbonne, 2011) and measurements of carbon isotopes in dolomite and calcite 
174 reference materials at NordSIMS have yielded a bias of $-0.33 \%$ per wt. $\%$ of $\mathrm{MgO}$ (MJW

175 unpublished data), similar to the reported bias for oxygen. This implies that $\mathrm{Mg}$-calcite with $\mathrm{Mg} / \mathrm{Ca}$

176 of $220 \mathrm{mmol} / \mathrm{mol}$ normalized against calcite will be approximately $2 \%$ too light. Assuming a similar

177 linearity in the IMF bias for carbon as has been demonstrated for oxygen, the effect will be

178 proportionally smaller at lower $\mathrm{Mg}$ abundance. The putative instrumental mass bias effect thus has a

179 relatively minor influence on the acquired isotope ratios and, given the much greater magnitude of

180 the observed differences, does not affect our interpretations. The regularly interspersed BYM

181 measurements were used to correct measured isotope ratios for any drift during the analytical session

182 (typically a cubic polynomial fit was made to the standard analyses) and for instrumental mass

183 fractionation (IMF). External precision on $\delta^{13} \mathrm{C}$ based on multiple analyses of the BYM standard was

$184<0.4 \%$ (SD). Carbon isotope compositions are reported in conventional $\delta$ notation relative to Vienna

185 PeeDee Belemnite (VPDB).

187 4. Results and discussion

188 4.1 SEM evidence for the presence of [cryptic] authigenic carbonate

189 SEM analyses reveal the presence of abundant diagenetic pyrite and authigenic carbonate on the

190 foraminiferal test walls (Fig. 2). Co-precipitation of these phases can be expected at the depth of the

191 SMTZ, because AOM results in the production of bicarbonate and hydrogen sulfide, which induces

192 precipitation of authigenic carbonate minerals and pyrite (Peckmann et al., 2001). These authigenic

193 carbonate overgrowths can be 'cryptic', i.e. they are not visible under optical microscope. For

194 instance, relatively well preserved tests with typical granular microstructure and wall pores and no

195 obvious evidence for authigenic carbonate overgrowths, contain clusters of framboidal pyrite inside

196 the test chambers (Fig. 2a-b). The extent of authigenic carbonate overgrowths can be highly variable

197 both between and within individual tests. In sediments from $132 \mathrm{~cm}$ bsf, tests without obvious

198 overgrowths (Fig 2a) and tests with thick overgrowths (Fig. 2h) co-occur. In some tests there is a 
gradient from thick overgrowths on the test walls of the outer chambers to thin overgrowths on the

200 test walls of the inner chambers in the umbilical region (Fig. 2c). The pores appear to act as a nuclei

201 for precipitation of authigenic carbonate, as suggested by linings of authigenic crystals around the

202 pores in the inner chambers (Fig. 2d). The outer chambers are variably covered with the overgrowths;

203 authigenic carbonate precipitation takes place in spaces between the pores (Fig. 2e) and eventually

204 the whole inner side of the test can become covered with microcrystalline overgrowths completely

205 masking the original surface features of calcite tests (Fig. 2f-h).

\subsection{Mg/Ca in biogenic calcite and authigenic carbonate overgrowths}

208 Morphological evidence for authigenic carbonate overgrowths on the tests from core PC06 is 209 supported by differences in the $\mathrm{Mg} / \mathrm{Ca}$ ratio of the original test calcite and the overgrowths. EBS 210 images and EPMA $\mathrm{Mg} / \mathrm{Ca}$ mapping show the presence of low EBS and relatively Mg-rich

211 overgrowths approximately $20 \mu \mathrm{m}$ thick, on both the inner and outer foraminiferal test walls (Fig. 3).

$212 \mathrm{The} \mathrm{Mg} / \mathrm{Ca}$ ratio of the overgrowths is as high as $220 \mathrm{mmol} / \mathrm{mol}$, while the $\mathrm{Mg} / \mathrm{Ca}$ ratio of the 213 original test calcite is $<10 \mathrm{mmol} / \mathrm{mol}$. The occurrence of Mg-rich authigenic phases is not however

214 limited to the overgrowths on test walls; these authigenic phases can also fill the original wall 215 porosity and pores within it.

216 Some specimens are compositionally laminated with distinct Mg-rich laminae (Fig. 3). The initial

217 lamination was likely formed during ontogenesis as calcite laminae are added to the pre-existing test 218 every time a new chamber is built. Calcite crystallites in such laminae have a radial appearance with 219 C-axes lying perpendicular to the lamination, facilitating high porosity (Erez, 2003). Organic material 220 deposited between the calcite laminae can also become porous upon mineralization of organic matter 221 resulting in porous laminae. These pores are likely susceptible to filling by authigenic $\mathrm{Mg}$-rich calcite 222 during diagenesis. The result is a systematic banding with alternating high and low $\mathrm{Mg} / \mathrm{Ca}$. 
223 Quantitative EPMA point analyses (ca. $2 \mu \mathrm{m}$ diameter spot) show that $\mathrm{Mg} / \mathrm{Ca}$ in $\mathrm{Mg}$-rich zones 224 ranges from 10-60 mmol/mol in thin interlayers and in-filled pores while thicker overgrowths can 225 have $\mathrm{Mg} / \mathrm{Ca}$ up to $220 \mathrm{mmol} / \mathrm{mol}$ (Table 3, Fig. 4). Given that the thin Mg-rich layers and pores are 226 commonly smaller than the analytical spot size of the EPMA, the measured $\mathrm{Mg} / \mathrm{Ca}$ ratios of the 227 authigenic carbonates are likely lower than the actual $\mathrm{Mg} / \mathrm{Ca}$ ratios due to contributions from 228 enclosing low-Mg phases. The $\mathrm{Mg} / \mathrm{Ca}$ ratio of foraminiferal calcite is a widely accepted and applied 229 proxy for ocean temperature (Bohaty et al., 2012; Elderfield and Ganssen, 2000; Garidel-Thoron et 230 al., 2005; Lea et al., 2000; Nürnberg et al., 2000), and variable Mg/Ca with distinct banding or 231 apparently random variations in calcite tests can be produced by temperature variations during 232 foraminiferal growth (Sadekov et al., 2005; Branson et al., 2013). However, these variations are 233 typically in the range $2-10 \mathrm{mmol} / \mathrm{mol}$. Given that $\mathrm{Mg} / \mathrm{Ca}$ ratios in the foraminifera from core PC06 234 are typically far higher than would be expected due to temperature effects or other environmental 235 factors (Toyofuku et al., 2000; Toler et al., 2001) it appears likely that the Mg-rich interlayers, in236 filled pores and overgrowths within the foraminiferal tests from core PC06 represent authigenic 237 precipitates. $\mathrm{Mg}$ abundance therefore serves as an effective tracer of the primary foraminiferal test 238 calcite vs secondary authigenic Mg-calcite.

$240 \quad 4.3$ Contact relationship between foraminiferal calcite and authigenic carbonate overgrowths

241 The TEM investigation of the contacts between the original foraminiferal calcite and the authigenic $242 \mathrm{Mg}$-calcite overgrowths was undertaken using two FIB foils milled from F1 (Fig. 5). EDX analyses 243 confirm the compositional contrast between the calcite test and the Mg-calcite overgrowth (Fig. 5b, 244 e-f). In addition, a sharp contact between the test and the overgrowth can be identified on high-angle 245 annular dark-field (HAADF) images due to changes in contrast caused by differences in chemical 246 composition (Fig. 5b-d). 
247 Selected area electron diffractograms (SAEDs) obtained from the contact zones covering both 248 foraminiferal tests and overgrowths (Fig. 5g-h) show that the mineral phases on both sides of the 249 contact are structurally identical, and the crystallographic orientation is maintained though the 250 contact. High-resolution transmission electron microscope (HRTEM) images also show that the 251 crystal lattice fringes are identical through the contact (Fig. 5i).

252 The TEM data thus indicate that foraminiferal calcite serves as an ideal nucleation template for the 253 diagenetic Mg-calcite which, despite its elevated $\mathrm{Mg}$ abundance, has identical structural 254 characteristics to the foraminiferal calcite. Thus the templating capabilities of foraminifera may 255 therefore affect the preservation of foraminifera even in environments where only minor carbonate 256 authigenesis occurs. Although there is a wide range of carbonates in marine sediments, and several 257 crystallographic faces are exposed, the strength of bonding at the interface is clearly strongly 258 dependent on the structure and chemistry of the substrate surface. Our investigation demonstrates that 259 foraminiferal calcite and authigenic $\mathrm{Mg}$-calcite can have identical lattice fringes, such that authigenic 260 Mg-calcite precipitates preferentially on foraminifera tests.

\subsection{Carbon isotopic composition of primary biogenic calcite vs secondary authigenic Mg-calcite}

263 Carbon isotope analyses on different parts of an individual test were performed on foraminifera F5

264 (Fig. 2). $\delta^{13} \mathrm{C}$ values ranged from $-3.9 \%$ to $-34.1 \%$. Isotopically lightest carbon was found within 265 the relatively thick Mg-calcite overgrowths, while the heaviest carbon was found within the 266 foraminiferal calcite walls where there is only a very small amount of authigenic carbonate in-filling 267 the test pores. It is likely that the lowest $\delta^{13} \mathrm{C}$ values obtained from the overgrowths represent the 268 isotopic composition of pore water DIC from which authigenic precipitates were derived. The 269 heaviest $\delta^{13} \mathrm{C}$ values, obtained from the foraminifera wall (-3.9\%), represent the carbon isotope 270 composition closest to the original composition of the foraminiferal calcite. Given the $15 \mu \mathrm{m}$ spot size of SIMS analyses, a minor contribution from authigenic $\mathrm{Mg}$-calcite in small pores (with $\delta^{13} \mathrm{C}$ of ca. - 
$34 \%$ ) within foraminifera walls can be expected. This contribution from in-filled pores has likely

273 caused a small shift towards more negative $\delta^{13} \mathrm{C}$ values from the original foraminiferal calcite

274 isotopic composition, which is not known, but is expected to be within normal marine values (ca. -1

275 to $1 \%$ ). The range of $\delta^{13} \mathrm{C}$ values in F5 (Fig.2) is mostly due to sputtering of different proportions of 276 the original biogenic calcite and the authigenic Mg-calcite overgrowth. The foraminiferal specimen $277 \mathrm{~F} 1$, which was visually relatively well preserved, also yields relatively low $\delta^{13} \mathrm{C}$ values of -7.7 and -

$278 \quad 11.3 \%$. This test contains abundant framboidal pyrite within its chambers, indicative of diagenetic 279 carbon and sulfur cycling, yet there is no obvious morphologic evidence for the presence of 280 authigenic carbonates. However, $\mathrm{Mg} / \mathrm{Ca}$ mapping by EPMA reveals the presence of several $\mathrm{Mg}$-rich 281 interlayers (Fig. 4; Table 3), suggesting that cryptic authigenic Mg-calcite occurs in this test that is 282 difficult to detect morphologically. Hence the negative $\delta^{13} \mathrm{C}$ values of $\mathrm{F} 1$ also reflect the influence of 283 methane-derived authigenic Mg-calcite on this specimen.

\section{5. Implications}

286 Precipitation of authigenic carbonates is expected to occur within sediments at the depth of the 287 SMTZ at sites of methane seepage. The SMTZ can be located close to the sediment-water interface if 288 the methane flux from depth is high, or deeper (a few $\mathrm{cm}$ to several tens of meters) below the 289 interface if the methane flux is low. Thus if the methane flux is high, authigenic carbonate 290 precipitation will be broadly coeval with the depositional age of foraminifera, and under these 291 conditions foraminifera with authigenic overgrowths can serve as tracers of methane emission 292 event(s) at the seafloor. On the other hand, precipitation of authigenic carbonates under low methane 293 flux conditions can occur tens to thousands of years after sediment deposition and is likely to be 294 decoupled from methane emissions at the seafloor. Predominance of aragonite typically reflects 295 authigenic precipitation under high methane flux close to the sediment-water interface while $\mathrm{Mg}$ 296 calcite is associated with lower fluxes and deeper precipitation (Aloisi et al., 2000). Trace element 
297 characteristics of authigenic carbonates can also be used for deciphering between precipitation under 298 relatively open, sea water influenced conditions close to the sediment-water interface and 299 precipitation in subsurface sediments isolated from the overlying water column (Crémière et al., 300 2016a). Precipitation ages of authigenic carbonates can be determined by U-Th dating (Teichert et al., 301 2003; Bayon et al., 2009; Crémière et al., 2016b), although this has not yet been attempted on 302 authigenic overgrowths on foraminifera.

303 Our analyses reveal the presence of authigenic carbonate overgrowths with low $\delta^{13} \mathrm{C}$ on foraminiferal 304 tests recovered from within sediments located both above (102 and $132 \mathrm{~cm} \mathrm{bsf})$ and below $(210 \mathrm{~cm}$ 305 bsf) the present-day depth of the SMTZ (184 cm bsf) in core PC06. This indicates that the depth of 306 the SMTZ has varied over time, presumably in response to variations in methane fluxes or lateral 307 shifts in conduit positions (e.g. Sauer et al., 2015), and the overgrowths might represent a 308 precipitation "event" within the sediments in response to a fluctuating SMTZ. However, with our 309 available data, we are unable to confirm whether any of the overgrowths were deposited close to the 310 seafloor (although the presence of $\mathrm{Mg}$-calcite points to precipitation below the sediment-seawater 311 interface), and without reliable age constraints it is not possible to correlate possible methane 312 emission and authigenic carbonate precipitation events with changes in climate parameters. For 313 example, the authigenic overgrowths that we observe at $200 \mathrm{~cm}$ bsf could have precipitated any 314 time between the deposition of this sediment interval (> $20000 \mathrm{ka}$; Panieri et al., 2016) and the 315 present day.

316 Our findings demonstrate that foraminiferal tests incorporate methane-derived, low $\delta^{13} \mathrm{C}$ authigenic $317 \mathrm{Mg}$-calcite that occurs as morphologically distinct overgrowths and as cryptic pore in-fill. The 318 ubiquitous presence of such authigenic precipitates on foraminifera in sediment records at sites of 319 methane seepage complicates the usage of foraminifera as archives of methane emissions at the 320 seafloor and as tracers of methane-derived DIC in the biomineralization environment because carbon 321 isotope signatures can be modified by incorporation of light carbon at the SMTZ below the sediment- 
water interface. Chemical cleaning protocols to remove adhering clays, organic material and Fe-Mn oxyhydroxide phases from foraminifera have been routinely applied in trace element studies (Boyle

324 and Keigwin, 1985; Rosenthal et al., 1999; Martin and Lea, 2002) and a weak acid leaching protocol 325 has also been designed to chemically remove diagenetic carbonates attached to the foraminifera shell 326 (Pena et al., 2008; Panieri et al., 2012; 2014; Consolaro et al., 2015). Isotope data obtained on such 327 chemically cleaned foraminifera from methane seep sites can show very low $\delta^{13} \mathrm{C}$ values (as low as $328 \quad 17.4 \%$ at Vestnesa Ridge) that have been interpreted to reflect the presence of methane-derived DIC 329 in the biomineralization environment (Panieri et al., 2014). Our observations of the tight intergrown 330 nature of biogenic calcite and authigenic $\mathrm{Mg}$-calcite however draws into question the effectiveness of 331 these cleaning procedures removing the authigenic carbonate precipitates including $\mathrm{Mg}$-calcite. It is 332 likely that authigenic carbonates, particularly the Mg-rich calcite that is notoriously difficult to 333 remove, remain after cleaning by weak acid leaching and cause anomalous secondary ${ }^{13} \mathrm{C}$-depletions 334 and elevated $\mathrm{Mg} / \mathrm{Ca}$ in chemically cleaned foraminifera. Moreover, these authigenic precipitates have 335 high $\mathrm{Mg} / \mathrm{Ca}$ that precludes reconstruction of past seawater temperature and thus assessment of the 336 linkages between seafloor methane emissions and climate change. We suggest that high-resolution 337 petrographic-elemental observations are therefore essential to ensure the authenticity of putative 338 biogenic calcite at methane seepage sites.

339 Our work reveals that even foraminiferal tests that appear well-preserved under optical microscope 340 and SEM may be diagenetically altered as a result of precipitation of authigenic phases at the depth 341 of the SMTZ at sites of methane seepage. This potentially compromises the value of foraminiferal $342 \delta^{13} \mathrm{C}$ and $\mathrm{Mg} / \mathrm{Ca}$ data as records of past environmental conditions at these locations influenced by 343 methane seepage both now and in the past. We show that fine scale analyses at sub- $\mu \mathrm{m}$ resolution 344 allow the unaltered biogenic calcite to be targeted and thus provide the framework to overcome the 345 challenges identified for the use of foraminifera as paleoceanographic proxies for past episodes of seafloor methane seepage and climate reconstruction. 


\section{Conclusions}

349 Our work on individual tests of benthic foraminifera in a sediment core from an area of methane 350 seepage offshore western Svalbard highlights the complexity of distinguishing between primary and 351 secondary signals. We demonstrate that diagenetic overprints on foraminifera can be extensive, but 352 not always evident using traditional methods such as optical microscopy. Moreover we show, for the 353 first time, that foraminiferal calcite and authigenic $\mathrm{Mg}$-calcite overgrowths have identical crystal 354 lattice fringes, meaning they are structurally identical, such that foraminifera serve as preferred 355 nucleation templates for authigenic $\mathrm{Mg}$-calcite.

356 High spatial resolution analyses utilizing advanced technologies show that the authigenic Mg-calcite 357 has much lower $\delta^{13} \mathrm{C}$ and higher $\mathrm{Mg} / \mathrm{Ca}$ than primary biogenic calcite. The low $\delta^{13} \mathrm{C}$ values indicate 358 the methane-derived origin of authigenic carbonate precipitating at the depth of the SMTZ. If the 359 SMTZ is located close to the seafloor, then authigenic Mg-calcite and biogenic calcite are broadly 360 coeval and provide a record of methane seepage at the seafloor. However, we caution that the depth 361 of the SMTZ can be located up to several meters below the sediment-seawater interface; in these 362 circumstances the authigenic $\mathrm{Mg}$-calcite is younger than the biogenic calcite and low $\delta^{13} \mathrm{C}$ values 363 cannot be interpreted in terms of methane emissions at the seafloor.

\section{ACKNOWLEDGMENTS}

367 This work was supported by the Research Council of Norway through its Centre of Excellence 368 funding scheme for CAGE, project number 223259, and partially supported by the UK Department 369 of Energy and Climate Change (DECC) as part of the Natural Environment Research Council 370 (NERC) Arctic Research Programme. We thank Trine Merete Dahl at the Department of Geology at 371 The Arctic University of Norway in Troms $\varnothing$ for technical support. 


\section{FIGURE CAPTIONS}

374 Figure 1. Location of core PC06 offshore western Svalbard in the Arctic Ocean.

376 Figure 2. SEM images of foraminifera F1-F5 (Table 1) from core PC06 that show different styles of 377 diagenetic alteration. In the images of foraminifera F1 and F5, red circles and associated numbers 378 show spots of SIMS analyses and obtained $\delta^{13} \mathrm{C}$ values (\%o VPDB; listed in Table 2). Red squares on $379 \mathrm{~F} 1, \mathrm{~F} 2, \mathrm{~F} 4$ and F5 indicate the areas where $\mathrm{Mg}$ mapping and $\mathrm{Mg} / \mathrm{Ca}$ point analyses were undertaken 380 (Fig. 3a, b, c, d respectively, and Table 3)

381 (a) Well preserved tests of $N$. labradorica (F1, from $132 \mathrm{~cm} \mathrm{bsf)} \mathrm{exhibiting} \mathrm{typical} \mathrm{granular}$ 382 microstructure and wall pores without obvious evidence of authigenic carbonate precipitates; infilling 383 of pyrite as framboids and small aggregates (ca. $3 \mu \mathrm{m}$ ) occurs inside the chambers (whitish areas). 384 (b) N. labradorica (F2, from $132 \mathrm{~cm}$ bsf;) with relatively well preserved tests exhibiting open wall 385 pores and the systematic banding of the wall tests. White blebs are framboidal pyrite aggregates. (c) M. barleeanus (F3, from $102 \mathrm{~cm}$ bsf). (d) Inner side of the test wall showing the foraminifera wall 387 pores rimmed by triangular crystals of Mg-calcite. (e) Carbonate precipitation has occurred on the 388 whole inner side of the test and the microcrystalline overgrowths completely mask the original 389 surface features of the test. The wall pores are apparently acting as nuclei for precipitation of 390 authigenic carbonate.

391 (f) $N$. labradorica (F4, from $210 \mathrm{~cm}$ bsf). (g) The whole inner side of the test is completely covered 392 with microcrystalline Mg-calcite overgrowths, masking the original surface features of the test. The 393 tops of the crystals appear as triangular prisms.

394 (h) N. labradorica (F5, from $132 \mathrm{~cm} \mathrm{bsf).} \mathrm{The} \mathrm{original} \mathrm{part} \mathrm{of} \mathrm{the} \mathrm{test} \mathrm{(light} \mathrm{grey} \mathrm{areas} \mathrm{in} \mathrm{the}$ 395 backscatter image) has been covered, both on the outside and on the inside, by elongated 396 rhombohedra crystals with sharp edges (i). SIMS data (Table 2) indicate that the secondary Mg- 
397 calcite overgrowths have low $\delta^{13} \mathrm{C}$ values.

399 Figure 3. Electron backscattered images and corresponding Mg distribution maps of cross sections of $400 N$. labradorica and M. barleeanus, for images of entire foraminifera tests see Fig. 2. Red circles show 401 locations of quantitative $\mathrm{Mg} / \mathrm{Ca}$ measurements (beam diameter: ca. $2 \mu \mathrm{m}$ ) reported in Table 3.

403 Figure 4. Electron backscattered images and relative $\mathrm{Mg}$ and $\mathrm{Ca}$ distribution maps (middle column 404 images where blue colors indicate low concentrations, green-red-pink colors indicate higher 405 concentrations) from cross sections of $N$. labradorica and $M$. barleeanus, for images of entire 406 foraminifera tests see Fig. 2. Triple images are the same place in the same individual. Red circles on 407 the images in the first column show locations of quantitative $\mathrm{Mg} / \mathrm{Ca}$ measurements (beam diameter: 408 ca. $2 \mu \mathrm{m}$ ) reported in Table 3 and Fig. 3. The images in the last column indicate Ca maps.

410 Figure 5. (a) Secondary electron microscope - backscatter electron (SEM-BSE) image of a fragment 411 of foraminifer F5 showing two locations (orange rectangles) where focused ion beam (FIB) foils, 412 shown on panels $b$ and d, were prepared. (b) High-angle annular dark-field (HAADF) image of entire 413 FIB foil milled from the inner side of the foraminifera test wall. Dotted line marks the contact 414 between foraminiferal calcite and the authigenic Mg-calcite overgrowth. Rectangles e and f give the 415 positions of EDAX analyses shown on panels e and f. (c) HAADF close up of the contact (dotted 416 line) between the foraminifera and authigenic overgrowth. Orange circle $\mathrm{h}$ gives the position of the 417 selected area electron diffractogram (SAED) shown on panel $\mathrm{h}$, and rectangle $\mathrm{j}$ gives the position of 418 high-resolution transmission electron microscope (HRTEM) image shown on panel j. (d) HAADF 419 image of entire FIB foil milled from the divider between the foraminifera chambers. Dotted line 420 marks the contact between foraminiferal calcite and the authigenic Mg-calcite overgrowth occurring 421 at both sides. Orange circle g gives the position of the SAED shown on panel g. (e-f) EDAX spectra 
422 obtained from foil $\mathrm{b}$ showing elevated $\mathrm{Mg}$ content in the authigenic overgrowth compared to 423 foraminiferal calcite where $\mathrm{Mg}$ is not detectable. $(\mathrm{g}-\mathrm{h})$ indexed SAED patterns from contact zones of 424 both foils showing a consistent diffraction pattern through contacts indicating structurally identical 425 phases with matching crystallographic orientations on both sides of contact. (i) HRTEM image from 426 the contact zone demonstrating identical lattice fringes across the contact.

\section{TABLE CAPTIONS}

429 Table 1. Bulk stable carbon isotope values of foraminifera from core PC06. Data are from Panieri et 430 al. (2016).

432 Table 2. Stable carbon isotope values of single foraminiferal tests ( $N$. labradorica, specimen 1 and 2) 433 analyzed with secondary ion mass spectrometry (SIMS). Values are expressed in \%o VPDB. 434 Locations of measurement spots are indicated in Fig. 2.

436 Table 3. Mg/Ca ratios measured in the inner and outer foraminiferal test walls. Locations of 437 measurement spots are represented in Fig. 4 and indicated in the foraminiferal tests in Fig. 5.

\section{REFERENCES CITED}

440 Aloisi, G., Pierre C., Rouchy J.M., Foucher J.P., Woodside J., and the Medinaut Scientific Party, 4412000 , Methane-related authigenic carbonates of eatern Mediterranean Sea mud volcanoes and 442 and their possible relation to gas hydrate destabilisation, Earth Planetary Science Letters, v. 184, 443 p. $231-338$.

444 Bayon, G., Henderson, G.M., and Bohn M., 2009, U-Th stratigraphy of a cold seep carbonate crust: 
Chemical Geology, v. 260, p. 47-56, http://dx.doi.org/10.1016/j.chemgeo.2008.11.020.

Berner, R., 1970, Sedimentary pyrite formation: American Journal of Science, no. 268, p. 1-23.

Blackmon, P. D., and Todd, R., 1959, Mineralogy of some foraminifera as related to their classification and ecology: Journal of Paleontology, v. 33, p. 1-15

Boetius, A., Ravenschlag, K., Schubert, C.J., Rickert, D., Widdel, F., Giesecke, A., Amann, R., Jorgensen, B.B., Witte, U., Pfannkuche, O., 2000, A marine microbial consortium apparently mediating anaerobic oxidation of methane: Nature v. 407, p. 623-626.

Bohaty, S.M., Zachos, J.C., and Delaney, M.L., 2012, Foraminiferal Mg/Ca evidence for Southern Ocean cooling across the Eocene-Oligocene transition: Earth Planetary Science Letters, v. 317318, p. 251-261.

Boyle, E.A., and Rosenthal, Y., 1996, Chemical hydrography of the south Atlantic during the Last Glacial Maximum: Cd vs. $\delta^{13}$ C. In: Wefer, G., et al. (Ed.), The South Atlantic: Present and Past Circulation. Springer, New York, p. 423-443.

Branson, O., Redfern, S.A.T., Tyliszczak, T., Sadekov, A.Y., Langer, G., Kimoto, K., and Elderfield,

Consolaro, C., Rasmussen, T. L. Panieri, G., Mienert, J. Buenz, S., and Sztybor, K., 2015, Carbon isotope ( $\square 13 \mathrm{C}$ ) excursions suggest times of major methane release during the last $14 \mathrm{kyr}$ in Fram

Crémière, A., Lepland, A., Chand, S., Sahy, D., Kirsimäe, K., Bau, M., Whitehouse, M.J., Noble, S.R., Martma, T., Thorsnes, T. \& Brunstad, H. 2016a, Fluid source and methane-related diagenetic processes recorded in cold seep carbonates from the Alvheim channel, central North Sea: Chemical Geology, v. 432, p. 6-33. 
468 Crémière, A., Lepland, A., Chand, S., Sahy, D., Condon, D.J., Noble, S.R., Martma, T., Thorsnes, T., 469 Sauer, S., \& Brunstad, 2016b. Timescales of methane seepage on the Norwegian margin 470 following collapse of the Scandinavian Ice Sheet. Nature Communications, in press.

471 de Garidel-Thoron, T.D., Rosenthal, Y., Bassinot, F., and Beaufort, L., 2005, Stable sea surface 472 temperatures in the western Pacific warm pool over the past 1.75 million years: Nature, v. 433, p. 473 294-298.

474 Dickens, G. R., O'Neil, J. R., Rea, D. K., and Owen, R. M., 1995, Dissociation of oceanic methane 475 hydrate as a cause of the carbon isotope excursion at the end of the Paleocene: Paleoceanography, 476 v. 10, no. 6, p. 965-971, doi:10.1029/95PA02087.

477 Elderfield, H., and Ganssen G., 2000, Past temperature and $\delta 180$ of surface ocean waters inferred 478 479 Hesselbo, S.P., Gröcke, D.R., Jenkyns, H.C., Bjerrum, C.J., Farrimond, P., Morgans Bell, H.S., and 480 Green, O.R., 2000, Massive dissociation of gas hydrate during a Jurassic anoxic event: Nature, v. $481 \quad 406$, p. 392-395.

482 Hill, T.M., Kennett, J.P., and Valentine, D.L., 2004, Isotopic evidence for the incorporation of 483 methane-derived carbon into foraminifera from modern methane seeps, Hydrate Ridge, 485 Jiang, G., Kennedy'M.M.J., and Christie-Blick, N., Stable isotope evidence for methane seeps in 486 Neoproterozoic postglacial cap carbonates: Nature, v. 426, p. 822-826.

487 Jørgensen, B., Böttcher, M., Lüschen, H., Neretin, L., and Volkov, I., 2004, Anaerobic methane 488 oxidation and a deep H2S sink generate isotopically heavy sulfides in Black Sea sediments: 489 Geochimica et Cosmochimica Acta, v. 68, p. 2095-2118, doi:10.1016/j.gca.2003.07.017. 490 Kennett, J. P., Cannariato, K. G., Hendy, I. L., and Behl, R. J., 2000, Carbon Isotopic evidence for 491 methane hydrate instability during Quaternary interstadials: Science, v. 288, p. 128-133. 
Lea, D.W., Pak, D.K., and Spero, H.J., 2000, Climate impact of late quaternary equatorial Pacific Sea surface temperature variations: Science, v. 289, p. 1719- 1724.

494 Martin, P.A., Lea, D.W., 2002, A simple evaluation of cleaning procedures on fossil benthic 495 foraminiferal Mg/Ca: Geochemistry, Geophysics, Geosystems, v. 3, no. 10, p. 8401, 496 doi:10.1029/2001GC000280.

497 Martin, R. A., Nesbitt, E. A., and Campbell, K. A., 2010, The effects of anaerobic methane oxidation 498 on benthic foraminiferal assemblages and stable isotopes on the Hikurangi Margin of eastern New Zealand: Marine Geology, v. 272, p. 270-284.

Meldrum, F.C., and Hyde, S.T., 2001, Morphological influence of magnesium and organic additives on the precipitation of calcite: Journal of Crystal Growth, v. 231, p. 544-558, ISSN 0022-0248.

502

Millo, C., Sarnthein, M., Erlenkeuser, H., and Frederichs, T., 2005, Methane-driven late Pleistocene $\square{ }^{13} \mathrm{C}$ minima and overflow reversals in the southwestern Greenland Sea: Geology, v. 33, pp. 873-876.

Nürnberg, D., Muller, and Schneider, R., 2000, Paleo-sea surface temperature calculations in the equatorial east Atlantic from $\mathrm{Mg} / \mathrm{Ca}$ ratios in planktic foraminifera: A comparison to sea surface temperature estimates from Uk37, oxygen isotopes, and foraminiferal transfer function: Paleoceanography, v. 15, p. 124-134.

Panieri, G., James, R. H., Camerlenghi, A., Westbrook, G. K., Consolaro, C., Cacho, I., Cesari, V., and Sanchez Cervera, C., 2014, Record of methane emissions from the West Svalbard continental margin during the last 23,500 years revealed by d13C of benthic foraminifera, Global Planetary Change, v. 122, p. 151-160.

Panieri, G., Graves, C.A., and James, R.H., 2016, Paleo-methane emissions recorded in foraminifera near the landward limit of the gas hydrate stability zone offshore western Svalbard: Geochemistry, Geophysics, Geosystems, v.17, p. 521-537, doi:10.1002/2015GC006153. 
516 Peckmann, J., Gischler, E., Oschmann, W., and Reitner, J., 2001, An Early Carboniferous seep community and hydrocarbon-derived carbonates from the Harz Mountains, Germany: Geology, v. 29, p. 271-274, doi: 10.1130/0091-7613.

Rosenthal, Y., Field, M.P., and Sherrell, R.M., 1999, Precise determination of element/calcium ratios in calcareous samples using sector field Inductively Coupled Plasma Mass Spectrometry: Analytical Chemistry, v. 71, no. 15, p. 3248-3253.

Sadekov, A.Y., Eggins, S.M., and de Deckker, P., 2005, Characterization of Mg/Ca distributions in planktonic foraminifera species by electron microprobe mapping: Geochemistry, Geophysics, Geosystems, v. 6, Q12P06.

Teichert B.M.A., Eisenhauer A., Bohrmann, G. Haase-Schramm, A. Bock B., and Linke, P., 2003, U/Th systematics and ages of authigenic carbonates from Hydrate Ridge, Cascadia Margin: recorders of fluid flow variations: Geochimica Cosmochimica Acta, v. 67, p. 3845-3857, http://dx.doi.org/10.1016/S0016-7037(03)00128-5. $\mathrm{Mg} / \mathrm{Ca}$ thermometry in foraminifera: Comparison of experimental results and measurements in nature: Paleoceanography, v. 15, p. 456-464.

Toler, S. K., Hallock, P., and Schijf, J., 2001, Mg/Ca ratios in stressed foraminifera, Amphistegina

538 Ussler III, W., and Paull, C. K., 2008, Rates of anaerobic oxidation of methane and authigenic 539 carbonate mineralization in methane-rich deep-sea sediments inferred from models and 
geochemical profiles: Earth and Planetary Science Letters, v. 266, p. 271-287, doi:10.1016/j.epsl.2007.10.056.

542 Walter, L.M., 1986. Relative efficiency of carbonate dissolution and precipita- tion during 543 diagenesis: a progress report on the role of solution chemistry. In Gautier, D.L. (Ed.), Roles of $544 \quad$ Organic Matter in Sediment Diagenesis. The Society of Economic Paleontologists and $545 \quad$ Mineralogists Special Publication, v. 38, pp. 1-11.

546 Wefer, G., Heinze, P.-M., and Berger, W. H., 1994, Clues to ancient methane release: Nature, v. 369 , p. $282,1994$.

548 Wirth, R., 2009, Focused Ion Beam (FIB) combined with SEM and TEM: Advanced analytical tools 549 for studies of chemical composition, microstructure and crystal structure in geomaterials on a 550 nanometre scale: Chemical Geology, v. 261, no. 3-4, p. 217-229, doi:

$551 \quad$ http://doi.org/10.1016/j.chemgeo.2008.05.019

552 Wright, D.T., and Wacey, D., 2004, Sedimentary dolomite - a reality check. The Geometry and 553 Petrogenesis of Dolomite Hydrocarbon Reservoirs: Geological Society, London, Special $554 \quad$ Publication v. 235, p. 65-74.

555 Zachos, J.C., Rhöl, U., Schellenberg, S.A., Sluijs, A., Hodell, D.A., Kelly, D.C., Thomas, E., Nicolo, 556 M., Raffi, I., Lourens, L.J., McCarren, H., and Kroon, D., 2005. Rapid acidification of the ocean 557 during the Paleocene-Eocene thermal maximum: Science, v. 308, p. 1611-1615, $558 \quad$ doi:10.1126/science.1109004

561 1GSA Data Repository item 201Xxxx, The data are stored at the Centre for Arctic Gas Hydrate, 562 Environment and Climate data repository and are accessible by contacting fabio.sarti@ uit.no., is 563 available online at www.geosociety.org/pubs/ft20XX.htm, or on request 

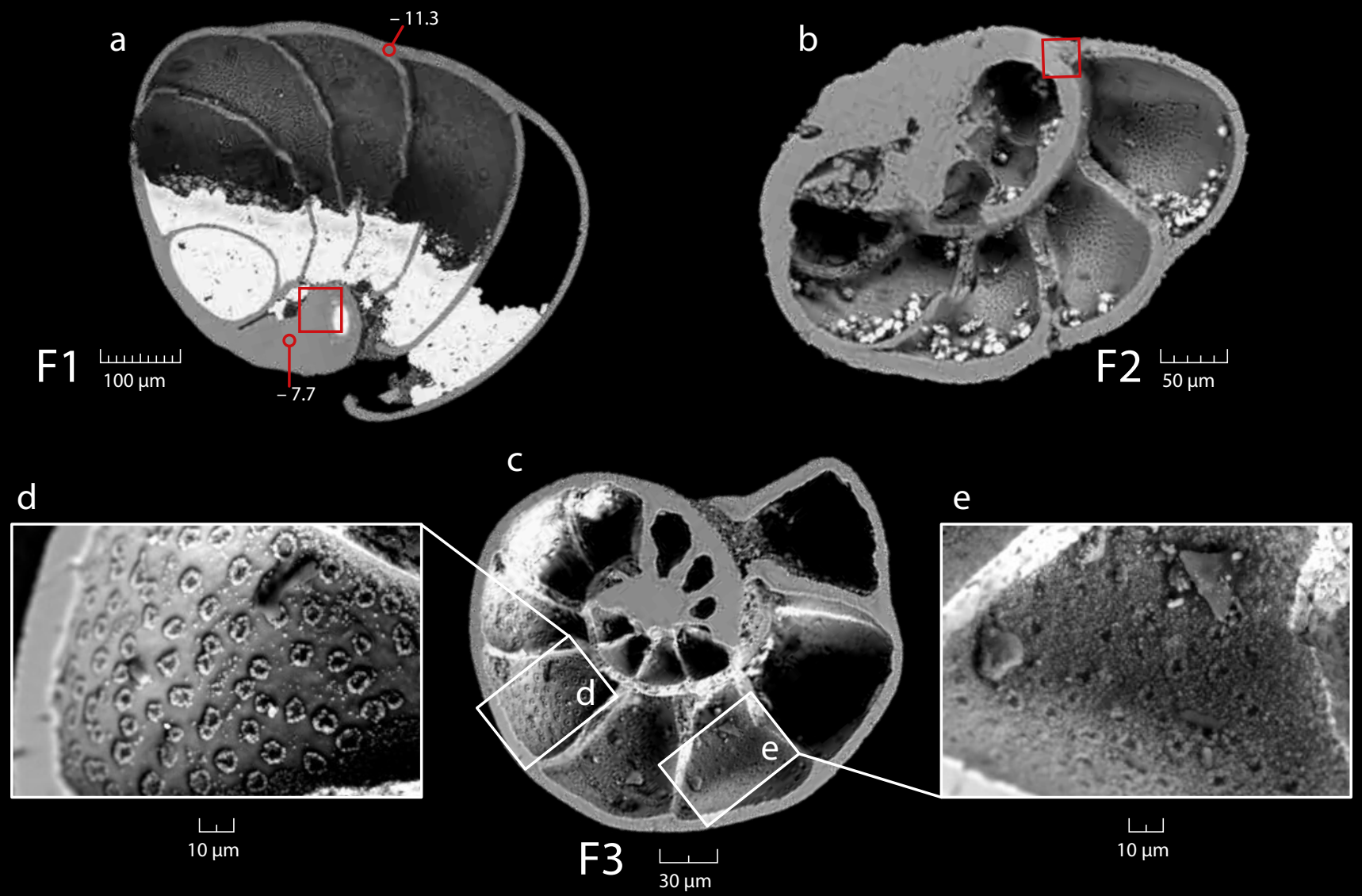

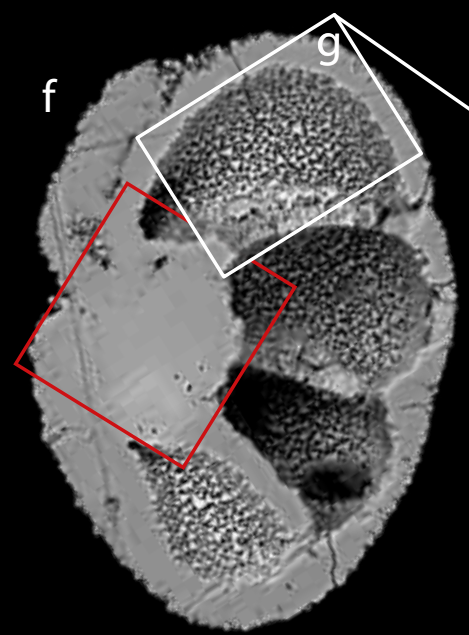

F4 $\underset{30 \mu \mathrm{m}}{\stackrel{\llcorner}{L}}$

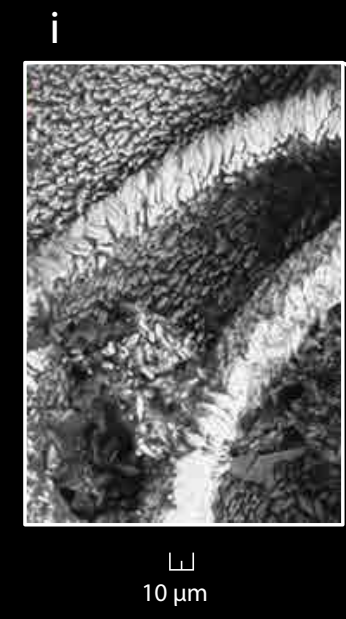

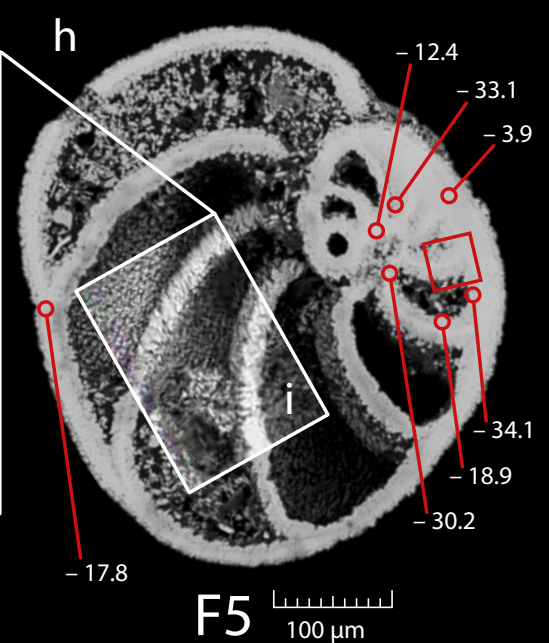

$\sqcup$
$3 \mu \mathrm{m}$

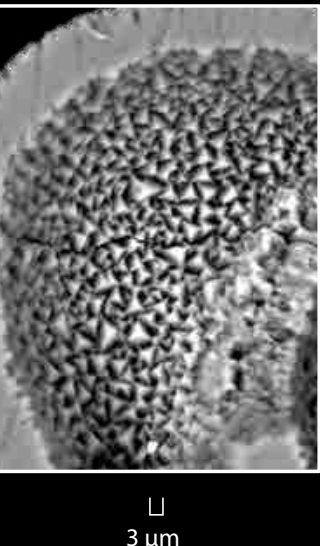

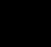




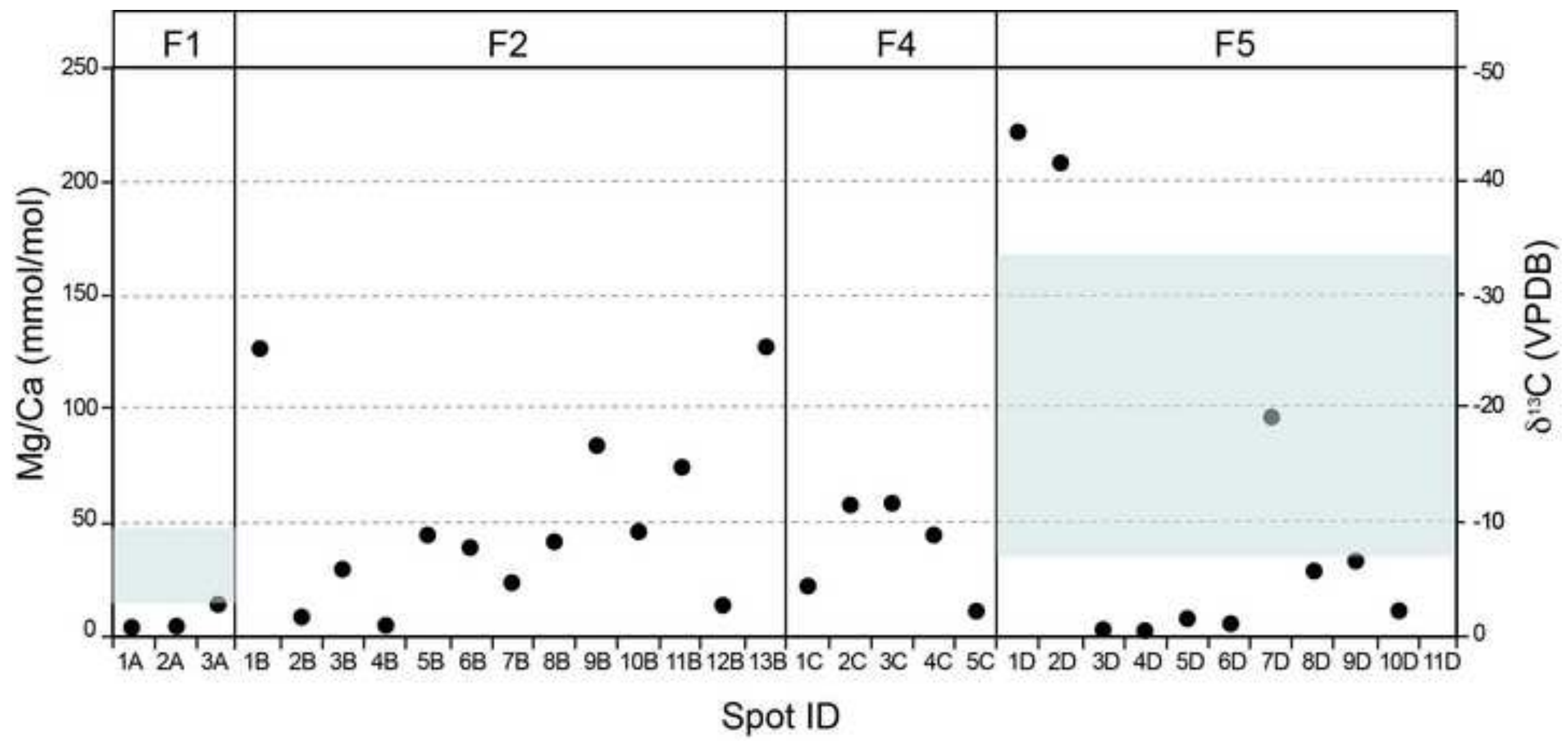


Table 1-3

Click here to download Table: Tables 1-3 revised.xlsx

\begin{tabular}{clcc}
\multirow{2}{*}{ Foraminifera } & \multicolumn{1}{c}{ Species } & Depth (cm bsf) & $\boldsymbol{\delta}^{\mathbf{1 3}} \mathbf{C}$ \\
\cline { 2 - 4 } & Nonionella labradorica (specimen 2) & 132 & -10.6 \\
F2 & Nonionella labradorica & 102 & -4.7 \\
F3 & Melonis barleenaum & 102 & -5.1 \\
F4 & Nonionella labradorica & 210 & -11.3 \\
F5 & Nonionella labradorica (specimen 1) & 132 & -10.6 \\
\hline
\end{tabular}

